\title{
Knowledge, Attitude and Eco-Efficiency Urban Environment in the Inhabitants of the District of Chilca - Peru
}

\author{
Ronald Héctor Révolo Acevedo ${ }^{1}$
}

Bimael Justo Quispe Reymundo'

Cirilo Walter Huamán Huamán ${ }^{1}$

Julio Cesar Álvarez Orellana ${ }^{1}$

Emilio Osorio Berrocal ${ }^{1}$

Janette Danizza Jauregui Ofracio ${ }^{1}$

Zosimo Solano Velarde ${ }^{1}$

Uriel Rigoberto Quispe Quezada²

Wilfredo Ramirez Salas ${ }^{1}$

\section{Carlos Enrique Álvarez Montalvan ${ }^{1}$}

${ }^{1}$ National University of the Center of Peru, Faculty of Forestry and Environmental Engineering, Mariscal Castilla 3909, Huancayo 12006. Peru

${ }^{2}$ National Autonomous University of Huanta, Jr. Manco Cápac 497, Huanta- Ayacucho, Peru

DOI: https://doi.org/10.36941/jesr-2022-0017

\section{Abstract}

The attitude is based on the self-concept or degree to which an individual perceives an integral part of the natural environment and situations with which it is related. Knowledge includes obtaining, analyzing and systematizing an individual from their natural environment, which is an important step for personal understanding and development. The objective of the research was to analyze and relate the environmental knowledge and attitude of 382 people towards urban-sustainable eco-efficiency in the inhabitants of the Chilca district. Two questionnaires [knowledge and attitude] of 23 questions were designed, the interview was personal to 382 people between the ages of 20 and 50 years. The questionnaire presented 5 responses using the Likert scale, the relationship was corroborated by hiring Rho Spearman and t-student statistical hypotheses. Result: The Environmental Knowledge towards Eco-efficiency (267, 290 and 225 has an idea totally in agreement in air and soil, biological diversity and climate change, respectively). The Environmental Attitude towards Eco-efficiency (200, 192 and 191 have an idea that is totally in agreement in their cognitive, affective and conative aspects, respectively). The relationship between $K$. and A. presents $a$ rho=0.47 being a good relationship, with con $t$-student $=10.35$ and $\alpha=2.2 e-16$; affirming that there is a relationship between the environmental attitude and environmental knowledge towards eco-efficiency. The inhabitants of Chilca affirm that knowledge and attitude are important and agree to mitigate, reduce and conserve biodiversity, air, soil and water, climate change from a cognitive, affective and conative perspective, forming an ecoefficient polymathic and environmental psychology for sustainable urban.

Keywords: knowledge, attitude, eco-efficiency and Environmental-Urban Sustainable Development 


\section{Introduction}

The accelerated development of urbanization has had a dramatic impact on the ecological environment (Fang \& Wang, 2013; Liu et al., 2012; Yin et al., 2014); causing inhabitants to use significant amounts of environmental resources through the production, processing, and factory of goods (Huang et al., 2018; Li et al., 2010; Zhang \& Yang, 2007), causing damage to air and soil, biological diversity, and an increase to climate change (Bai et al., 2018; Bohne et al., 2008; Zheng, 2010); constituting an empirical relationship in economic activities between environmental costs and environmental impact (Fang \& Wang, 2013; Fernández Viñé et al., 2010), who conceptualizes ecoefficiency (Glauser \& Müller, 1997; Huppes \& Ishikawa, 2008; Lloclla \& Arbulú, 2014). The ecoefficiency of cities based on their natural resources can vary according to the number of inhabitants (Caiado et al., 2017; Fernández et al., 2021; Huang et al., 2018), this is fundamental to achieve environmental sustainability goals (Basuki, 2015; Caiado et al., 2017; Frischknecht, 2010; Leal, 2005), i.e., it aims to ensure decent and equitable welfare for all people (Arévalo \& Cueva, 2019; Diaz, 2019; Hoffrén, 2001) and, at the same time, reduce environmental degradation to a level that is sustainable (Austermühle, 2012; Basuki, 2015; Caiado et al., 2017; Fernández et al., 2021; Frischknecht, 2010).

Eco-efficiency has a positive impact (Diaz, 2019; Fang \& Wang, 2013; Huang et al., 2018; Ruelas Llerena, 2017; Yin et al., 2014), in saving resources such as energy and water, as well as proper solid waste management (Diaz, 2019; Fernández et al., 2021; Zhang \& Yang, 2007), being extremely important for the future (Glauser \& Müller, 1997; Hoffrén, 2001; Huppes \& Ishikawa, 2008; Leal, 2005; Montes, 2008; Zhang \& Yang, 2007) so, not only can reflect the relationship between economy, environment and resources (Austermühle, 2012; Basuki, 2015; Caiado et al., 2017; Frischknecht, 2010), but can also comprehensively assess the degree of harmony in each field of resources, knowledge and an environmental attitude (Bleischwitz, 2003; Condori, 2016; Czibere et al., 2020; Fernández et al., 2021; Yin et al., 2014). Knowledge is important to determine environmental issues oriented to air, soil (Barreiro et al., 2002; Sonja et al., 2018), biodiversity and climate change problems (Barreiro et al., 2002; Berenguer, 1998; Chuliá, 1995; Holahan, 2012), who does not exclude eco-efficiency; an environmental knowledge and attitude are limited to aspects of environmental problems (Arteaga et al., 2019; Booi Chen \& Teck Chai, 2010; Holahan, 2012; Parillo et al., 2019; Portal, 2018; Sonja et al., 2018).

People's knowledge and attitude is reflected and related to the deterioration of natural resources and demographic attributes (Álvarez \& Vega, 2009; Barreiro et al., 2002; Berenguer, 1998; Booi Chen \& Teck Chai, 2010; Zhang \& Yang, 2007). Environmental attitude and knowledge also reflect the citizen's form to a sustainable behavior of the environment (Álvarez \& Vega, 20o9; Fang \& Wang, 2013; Holahan, 2012; Parillo et al., 2019), which is manifested in their affective, cognitive and conative state (Berenguer, 1998; Bleischwitz, 2003; Chuliá, 1995; Czibere et al., 2020; Holahan, 2012). The dimension of environmental attitudes is important from the point of view of eco-efficiency (Bleischwitz, 2003; Sonja et al., 2018; Zheng, 2010), because, it helps to refine and understand environmental problems at a personal level (Arteaga et al., 2019; Bleischwitz, 2003; Booi \& Teck, 2010; Czibere et al., 2020; Fang \& Wang, 2013; Parillo et al., 2019; Sonja et al., 2018; Zheng, 2010); an affective attitude directs feelings of concern such as the severity or degree of a problem occurring (Berenguer, 1998; Bleischwitz, 2003; Booi \& Teck, 2010; Chuliá, 1995; Czibere et al., 2020; Holahan, 2012; Sonja et al., 2018); a cognitive attitude routes information, responsibility in matter and knowledge (Âlvarez \& Vega, 2009; Barreiro et al., 2002; Bleischwitz, 2003; Holahan, 2012; Liu et al., 2012; Zhang \& Yang, 2007; Zheng, 2010); and, a conative attitude orients an ability to act personally under criteria of perception and willingness to take responsibility (Berenguer, 1998; Booi \& Teck, 2010; Cabana, 2017; Condori, 2016; Fang \& Wang, 2013; Holahan, 2012; Sonja et al., 2018; Zheng, 2010), all responding to environmental problems (Czibere et al., 2020; Fernández et al., 2021).

There is much theoretical information that affirms and considers important to know how attitude and knowledge can be mutually related so that urban development in many places is ecoefficient and sustainable (Fang \& Wang, 2013; Huang et al., 2018; Zheng, 2010), considering the 
individual personal perception of each person limiting the eco-environmental resources of her (Czibere et al., 2020; Fernández et al., 2021; Liu et al., 2012). Therefore, understanding eco-efficiency, knowledge and urban environmental attitude is an effective way of knowing if there is a sustainable environmental-urban development (Bleischwitz, 2003; Czibere et al., 2020; Fang \& Wang, 2013; Huang et al., 2018; Zhang \& Yang, 2007). Therefore, the objective of the research is to analyze, relate the knowledge and the environmental attitude towards sustainable urban eco-efficiency in the inhabitants of the Chilca district, Huancayo.

\section{Methodology}

\subsection{Study area}

The surveyed inhabitants are located in the district of Chilca, located in the department of Huancayo, Peru; with geographical location Log.: $75^{\circ} 12^{\prime} 30.01$ "W and Lat.: $12^{\circ} 5^{\prime} 11.39$ "S, at about 3275 m.a.s.l. with an extension of $830 \mathrm{Ha}$. The district of Chilca presents the following territorial resources of land use: Land with extensive crops $4.94 \mathrm{~km}^{2}$; Land with forests $7.23 \mathrm{~km}^{2}$; Urban areas and/or government and private facilities $6.43 \mathrm{~km}^{2}$; Unused and/or unproductive land $0.49 \mathrm{~km}^{2}$; Land with fruit orchards and other perennial crops $1,87 \mathrm{~km}^{2}$ and Natural grasslands areas $5,86 \mathrm{~km}^{2}$.

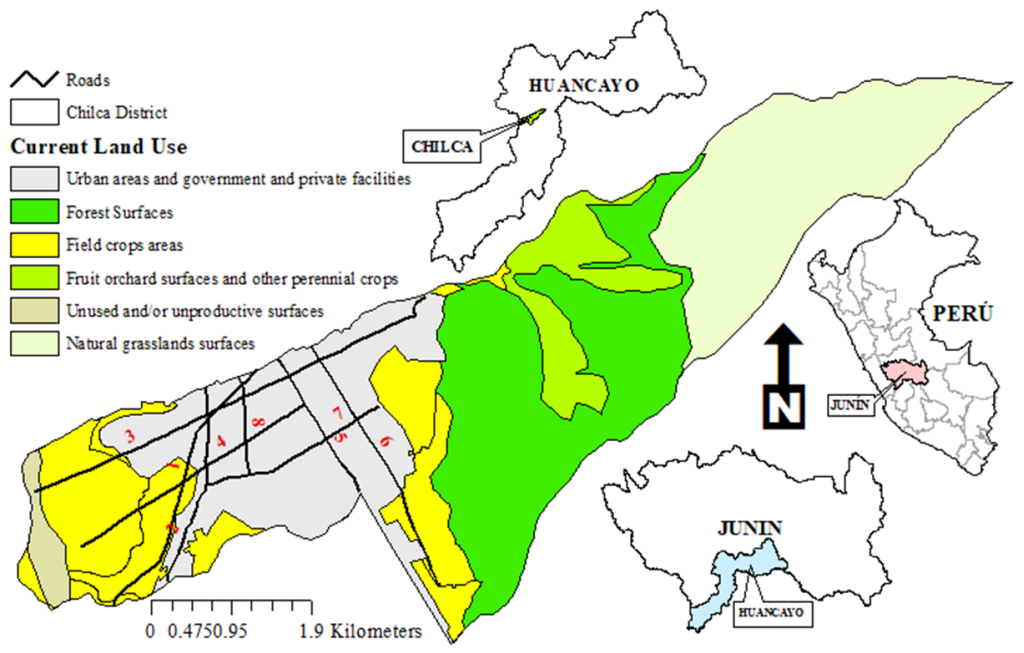

Figure 1: Chilca district location. The numbers in [1 - 8] represent the main Urban Avenues of the district.1: Railroad Avenue; 2: Panamerican's highway; 3: Leoncio Prado Avenue; 4: December nine Avenue; 5: Royal Avenue; 6: Jacinto Ibarra Avenue; 7: Próceres Avenue and 8: Huancavelica Avenue. Source: self-made.

\subsection{Sample and Survey Model}

Avenues with the highest demographic density in the Chilca district were selected. Applying a probabilistic sample selected a total of 382 inhabitants (respondents), 8 main avenues were selected (1: Railroad Avenue; 2: Panamerican's highway; 3: Leoncio Prado Avenue; 4: December nine Avenue; 5: Royal Avenue; 6: Jacinto Ibarra Avenue; 7: Próceres Avenue and 8: Huancavelica Avenue) within the district. 
Where:

$$
\mathrm{n}=\frac{\frac{\mathrm{z}^{2} * \mathrm{p}(1-\mathrm{p})}{\mathrm{e}^{2}}}{1+\frac{\mathrm{z}^{2} * \mathrm{p}(1-\mathrm{p})}{\mathrm{e}^{2} * \mathrm{~N}}}
$$

- $\quad \mathrm{n}$ : probabilistic sample [382 people to be surveyed].

- $\quad \mathrm{N}$ : total of the population between the age of 20 to 50 years [59732 people in total].

- $\quad \mathrm{z}$ : $\mathrm{z}$ score (The $\mathrm{z}$ score is the number of standard deviations that a given proportion deviates from the mean) [1.96].

- e: margin of error (percentage expressed in decimals) [5\%].

- p: confidence level [95\%].

\subsection{Survey format and Sampling}

The interview is personal [three people per family] the survey is aimed at people between 20 and 50 years old. Two survey models were elaborated. The first survey model evaluates the knowledge of the inhabitants, and is made up of 23 items, evaluating three dimensions: air and soil (10 items), biological diversity ( 7 items) and climate change ( 6 items). The second survey model answers the three dimensions of environmental attitude composed of a total of 23 items: cognitive (o9 items), affective (o7 items) and conative (o7 items).

Table 1: Questionnaire on Environmental Knowledge towards Eco-efficiency.

\begin{tabular}{|c|c|c|c|c|}
\hline \multirow{2}{*}{$\mathbf{N}^{\circ}$} & \multirow{2}{*}{ Items } & \multicolumn{3}{|c|}{ Scale } \\
\hline & & \begin{tabular}{|l|l|l|l}
1 & 2 \\
\end{tabular} & 23 & 455 \\
\hline 01 & Do you think there has been a lot of air pollution in your district in recent years? & & & \\
\hline 02 & $\begin{array}{l}\text { You believe that with the change in land use that responsible consumption has been taking place or has } \\
\text { changed. }\end{array}$ & & & \\
\hline 03 & You, change agricultural practices implementing adapting to changes in the climate. & & & \\
\hline 04 & Do you think that you can be affected by a lot of air pollution in some activities that you develop. & & & \\
\hline 05 & You believe that on the importance of the territorial ordering of your locality. & & & \\
\hline 06 & You have attended a talk about air pollution and land use. & & & \\
\hline 07 & You believe in the last decades the level of agricultural production has dropped. & & & \\
\hline 08 & You believe that there is a decrease in livestock and pasture planting. & & & \\
\hline 09 & You consider that urbanization will bring effects and causes in changes in the soil environment. & & & \\
\hline 10 & He believes that the use of agrochemicals in soils affects biodiversity. & & & \\
\hline 11 & $\begin{array}{l}\text { Biodiversity refers to all living beings on the planet, plants, animals, fungi including human beings, you } \\
\text { consider these elements to be very important. }\end{array}$ & & & \\
\hline 12 & Would it affect you if biodiversity was being lost? & & & \\
\hline 13 & Do you think it is necessary to protect biodiversity. & & & \\
\hline 14 & At one time he attended talks on biodiversity. & & & \\
\hline 15 & He believes that the way things are going, within 10 years the flora and fauna will be extinct. & & & \\
\hline 16 & In your opinion, is it necessary to protect biodiversity? & & & \\
\hline 17 & The consumption habits of society, do they influence the loss of biodiversity?. & & & \\
\hline 18 & Have you ever participated in a climate change training? & & & \\
\hline 19 & Do you believe that the municipality manages a system of climate change indicators. & & & \\
\hline 20 & You consider yourself at risk from climate change. & & & \\
\hline 21 & You believe that climate change can be made to slow down. & & & \\
\hline 22 & Do you think climate change influences water quality? & & & \\
\hline 23 & $\begin{array}{l}\text { You consider that the charge for consumption of water use in the community made by the Municipal } \\
\text { Authority is excessive. }\end{array}$ & & & \\
\hline
\end{tabular}

Note: Surveys numbered [o1 - 10] are questions related to air and soil, the numbered questions [11 - 17] correspond to biodiversity and questions $[18-23]$ are according to climate change. The vowels affirm the following answer: [1: Strongly Agree]; [2: Agree]; [3: Neither Agree nor Disagree]; [4: In Disagreement]; [5: Strongly Disagree]. 
Table 2: Questionnaire on the Environmental Attitude towards Eco-efficiency.

\begin{tabular}{|c|c|c|c|c|c|}
\hline \multirow{2}{*}{$\mathbf{N}$} & \multirow{2}{*}{ Items } & \multicolumn{4}{|c|}{ Scale } \\
\hline & & $\mathbf{1}$ & 2 & & 5 \\
\hline 01 & You know the management of household solid waste. & & & & \\
\hline 02 & You were informed about the importance of the environment to people. & & & & \\
\hline 03 & You know about the importance of the territorial ordering of your locality. & & & & \\
\hline 04 & You think it costs a lot to reduce pollution to protect the environment. & & & & \\
\hline 05 & The community participates in union programs for environmental protection. & & & & \\
\hline 06 & $\begin{array}{l}\text { Someone in your household has received training on environmental issues, such as such as: Soil, water } \\
\text { and air pollution. }\end{array}$ & & & & \\
\hline 07 & The municipality has had lawsuits or complaints from the community for soil contamination. & & & & \\
\hline 08 & $\begin{array}{l}\text { The district municipality has motivational and training programs on environmental issues, especially air } \\
\text { protection. }\end{array}$ & & & & \\
\hline 09 & I would like to take an active role in solving problems that cause air pollution. & & & & \\
\hline 10 & Values the importance of rejecting the consumption of products that are harmful to the environment. & & & & \\
\hline 11 & You value the potentialities of local and regional biodiversity. & & & & \\
\hline 12 & You value the proper use of water, soil and air. & & & & \\
\hline 13 & Values the importance of recycling solid waste. & & & & \\
\hline 14 & When I see someone littering, I want to get their attention. & & & & \\
\hline 15 & I'd be willing to give up certain amenities to save water. & & & & \\
\hline 16 & When recycling solid waste makes me feel like a good person who is concerned about the environment. & & & & \\
\hline 17 & You participate in environmental projects that are carried out in your neighborhood. & & & & \\
\hline 18 & You leave the spout open when you perform your hygiene needs. & & & & \\
\hline 19 & You use water rationally in your home or workplace. & & & & \\
\hline 20 & You worry about leaving your computer off if you don't use it anymore. & & & & \\
\hline 21 & You participate in environmental projects that are carried out in your neighborhood. & & & & \\
\hline 22 & I would like to take an active role in solving problems that cause air pollution. & & & & \\
\hline 23 & I don't want to attend rallies related to pollution and environmental problems. & & & & \\
\hline
\end{tabular}

Note: Surveys numbered [o1 - o9] are questions related to cognitive perception, the numbered questions [10 - 16] correspond to affective perception and questions [17 - 23] are according to conative perception. The vowels affirm the following answer: [1: Strongly Agree]; [2: Agree]; [3: Neither Agree nor Disagree]; [4: In Disagreement]; [5: Strongly Disagree].

\subsection{Validity, reliability of the instrument, correlation analysis and statistical hypothesis}

The survey has the Validity through the Likert scale, allowing to measure the perspectives and to know the level of congruence of the questionnaire through 5 levels [Strongly Agree; Agree; Neither Agree nor Disagree; In Disagreement and Strongly Disagree], both applied in attitude and knowledge. The statistical correlation and hypothesis analysis was performed by means of the Spearman rho rank correlation coefficient test; if the values are close to 1 or -1 , there will be a perfect correlation, either positive or negative. The statistical hypothesis was performed using the Student's t-test with a significance level of $\alpha=0.5$ bilateral [382, Student's t-student $=1.98$ ], using Rstudio software.

$$
\text { rho }=1-\frac{6 * \sum_{i=1}^{\mathrm{n}} \mathrm{d}^{2}}{\mathrm{~N}\left(\mathrm{~N}^{2}-1\right)} \quad[2] ; \mathrm{t}-\text { test }=\frac{\mathrm{rho} * \sqrt{\mathrm{N}^{\circ}-2}}{\sqrt{1-\mathrm{rho}^{2}}} ; \mathrm{df}=\mathrm{N}^{\circ}-2
$$

Where:

- rho: correlation coefficient.

- d: difference between corresponding statistics of order $[\mathrm{x}-\mathrm{y}]$.

- $\quad \mathrm{N}$ : number of data pairs.

- df: degrees of freedom

- $\quad \mathrm{N}^{\circ}$ : total data

- t-test: correlation hypothesis contrasting coefficient. 


\section{Results}

\subsection{Knowledge and Environmental Attitude at a Personal Level towards Eco-efficiency}

The surveys conducted with the inhabitants of the district of Chilca, have different ideas, knowledge and attitude towards urban eco-efficiency. Figure 2 shows 4 avenues that have a higher opinion in this regard, i.e. which avenues have a higher appreciation for having a knowledge and attitude to preserve the environment with an eco-efficient character to develop a sustainable environment.

Leoncio Prado Avenue with a total number of 94 people surveyed; at a personal level has the idea of total agreement with 87 opinions regarding a cognitive attitude, 75 affective and 76 cognitive; and, at a personal level has an idea of agreement in air and soil knowledge with 74, biological diversity 72 and climate change 70 ; this means that the majority of people living in Leoncio Prado Avenue have a behavior and knowledge to save in an eco-efficient way and protect the environment. The December nine Avenue with a total number of 47 people surveyed; the personal level has an idea of agreement with 36 opinions regarding a cognitive attitude, 35 affective and 32 conative; and, regarding environmental understanding has an idea of agreement in ideas of air and soil with 35 , biological diversity 32 and climate change has the idea totally in agreement with 36 opinions; thus affirming that the majority of the people of said avenue have a general idea of conserving the environment in an ecoefficient way. In the Railroad Avenue most of the people have an idea in agreeing in cognitive attitude with 37, affective 39 and conative 32; and regarding knowledge it has two ideas in agreeing in air and soil with 45 , biological diversity 42 and the idea of totally agreeing with 37 people at people level; therefore, most of the people of that avenue have an environmental knowledge and attitude towards ecoefficiency. And finally, Proceres Avenue with a total of 48 people surveyed presents an idea of agreement regarding attitudes and knowledge in affective state with 35, cognitive 36 , conative 32 , air and soil 38 , biological diversity 40 , and they have the idea totally in agreement in the topic of climate change with 39 opinions at a personal level; this means that the people of Proceres Avenue have the idea of conserving the environment from an eco-efficient perspective towards an urban development.
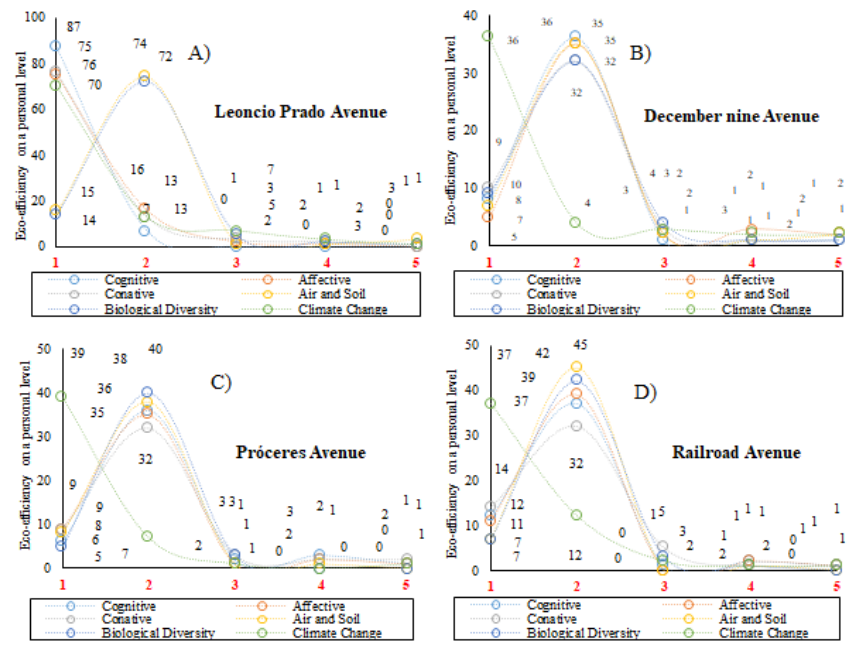

Figure 2: Perception of eco-efficiency at a personal level represented by their knowledge and environmental attitude in the Railroad Avenue; Leoncio Prado Avenue; December nine Avenue; Próceres Avenue. The numerical values of the $\mathrm{x}$-axis $[1-5]$ in red represent the scale and response of the perception in terms of attitude and environmental knowledge based on the eco-efficiency of each person [1: Strongly Agree; 2: Agree; 3: Neither Agree nor Disagree; 4: In Disagreement; 5: Strongly Disagree]. 
People's perception of Panamerican's highway at a personal level is in agreement that their cognitive opinion 17 , affective 20 , conative 26 , air and soil 21, biological diversity 33 and climate change 29 are considered of greater importance to be a very eco-efficient district. Likewise, the opinion of the people of Royal Avenue also feels its inclination of totally agree to agree that there is a good perception on a personal level the importance of attitudinal indicators and environmental knowledge to present a good sustainable urban eco-efficiency. This perception is also considerable on the part of the inhabitants of Jacinto Ibarra Avenue where 16, 9, 20, 17, 21 and 12 people are the ones with the highest opinion on a personal level, they consider to agree that environmental attitudes and knowledge is important for the urban eco-efficiency and finally, there is also a lot of favorable inclination on the part of the inhabitants of Huancavelica Avenue when they consider that they totally agree with their environmental concern in considering eco-efficiency as the main point for sustainable urban development.
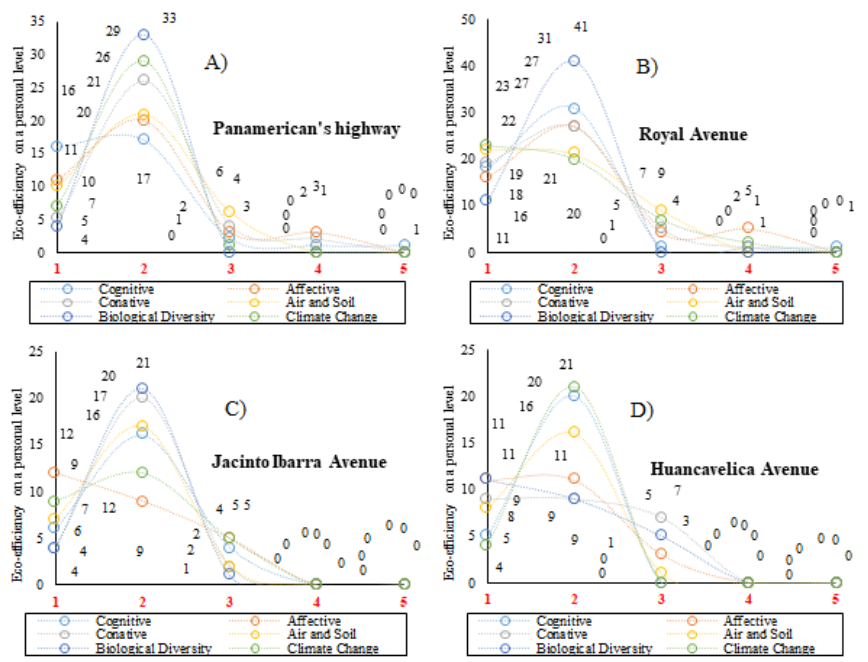

Figure 3: Perception of eco-efficiency at a personal level represented by their knowledge and environmental attitude in the Panamerican's highway; Royal Avenue; Jacinto Ibarra Avenue; Huancavelica Avenue. The numerical values of the $\mathrm{x}$-axis $[1-5]$ in red represent the scale and response of the perception in terms of attitude and environmental knowledge based on the eco-efficiency of each person [1: Strongly Agree; 2: Agree; 3: Neither Agree nor Disagree; 4: In Disagreement; 5: Strongly Disagree].

\subsection{Environmental Knowledge towards Eco-efficiency}

The analysis of the environmental knowledge towards eco-efficiency is interpreted in Figure 4, the knowledge is interpreted in 3 indicators who sum up separately the total appreciation of people surveyed: to have an environmental knowledge towards eco-efficiency in the care of air and soil 267 people have the idea of being in agreement, the idea of these people have the culture of saving these resources to have an eco-efficient environmental development and 5 people have an idea totally disagree in taking care of such resource (air and soil).

An environmental knowledge towards eco-efficiency in the care of biological diversity 290 people have the notion of being in agreement, it is to point out that such amount of people possess a feeling of eco-environmental saving before the interventions of biological diversity and about 2 people are the idea totally in disagreement in taking care of biological diversity. And to present an environmental knowledge towards eco-efficiency in the topic of climate change a total of 225 people 
have the idea of totally agreeing, it is to indicate that these people have the knowledge that environmental problems and to the non-eco-efficient conservation occur environmental changes creating climate change and about 5 people have the absurd idea in totally disagreeing to occur climate change by not having eco-efficient saving.

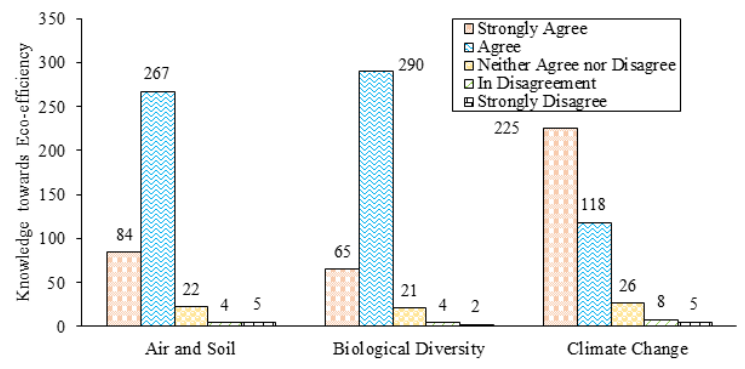

Figure 4: Total Environmental Knowledge of the inhabitants of the Chilca district towards Ecoefficiency. The level of Environmental Knowledge: air and soil, biological diversity and climate change separately add up to 382 , which corresponds to the total number of people surveyed by indicator.

\subsection{Environmental Attitude towards Eco-efficiency}

The observation of environmental attitude towards eco-efficiency is explained at a general level in Figure 5, the behavioral environmental attitude is interpreted by 3 indicators, who sum up at indicator level the total of people surveyed: to obtain a cognitive environmental attitude towards ecoefficiency indicates that 158 people have an idea of total agreement in having information and knowledge about the environmental problems that interfere in having a personal eco-efficiency and 5 people have the idea of total disagreement in presenting information and knowledge in this regard. The idea of having an affective environmental attitude towards eco-efficiency corresponds to 150 people, i.e. these people have the idea of totally agreeing with the seriousness, concern, priority and values of the environmental problems that interfere in having an eco-efficient urban development and 4 people have the absurd idea of totally disagreeing with the environmental problems that interfere in having an eco-efficient city at a personal level. And an environmental conative attitude towards eco-efficiency belongs to 146 people who have the idea of totally agreeing to act personally with ecological and eco-efficient criterion through perception, disposition and assuming before the environmental problems that happen and 34 people have the awkward idea of totally disagreeing before the environmental problems that happen in order to have an eco-efficient environmental city.

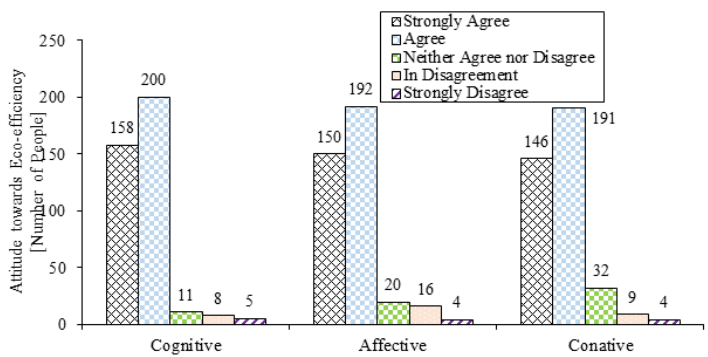

Figure 5: Total environmental attitude of the inhabitants of the Chilca district towards ecoefficiency. The Environmental attitude: cognitive, affective and conative individually add up to 382 , which corresponds to the total number of people surveyed by indicator. 


\subsection{Environmental Knowledge and Attitude towards Eco-efficiency}

In order to analyze the association at a personal level between environmental knowledge and environmental attitude towards eco-efficiency, both concepts were related; Figure 6 shows the relationship between both at a personal level. The distribution of the points in the concept of being in "totally agree" to being in "totally disagree" conceptualized and at the same time affirmed the existence of a relationship between attitude and knowledge; it is to mention that, having an environmental knowledge and attitude towards eco-efficiency is totally agree from a perspective, at a lower personal level to a higher personal level (being it equal and contrary to the ideas: "agree", "neither agree nor disagree" and "disagree"), conceptualizing that people possess a knowledge and/or idea in air and soil issues, biological diversity and climate change who should save or avoid causing more damage to the environment from a cognitive affective and conative attitudinal perspective. The following research hypothesis is proposed:

Ha: Understanding and linking the attitude and environmental knowledge towards ecoefficiency in the inhabitants of the Chilca district is important for sustainable urban development.

Ho: Ignoring and undifferentiating the attitude and environmental knowledge towards ecoefficiency in the inhabitants of the Chilca district is not important for sustainable urban development.

Many of the people agree and at the same time understand that attitude and knowledge are important to know about the environmental problems that affect their urban development and this can be improved through eco-efficiency. Linking knowledge and attitude strengthens that many people think about efficiently using biodiversity, water, soil, air and mitigating climate change, highlighting eco-efficiency for sustainable urban development; This is verifiable by hypothesis corroboration (Figure 6). All this analysis was corroborated by means of the statistical hypothesis test having as a result a Spearman $r h o=0.47$ which describes that it presents a "good or significant relationship" and $t$-test $=10.35>1.98(0.05 ; 382)$ at a significance level of $\alpha=0.5>2.2 e^{-16}$ bilateral, thus affirming that, if there is a relationship between environmental knowledge and environmental attitude towards eco-efficiency, to have a sustainable urban environmental development.

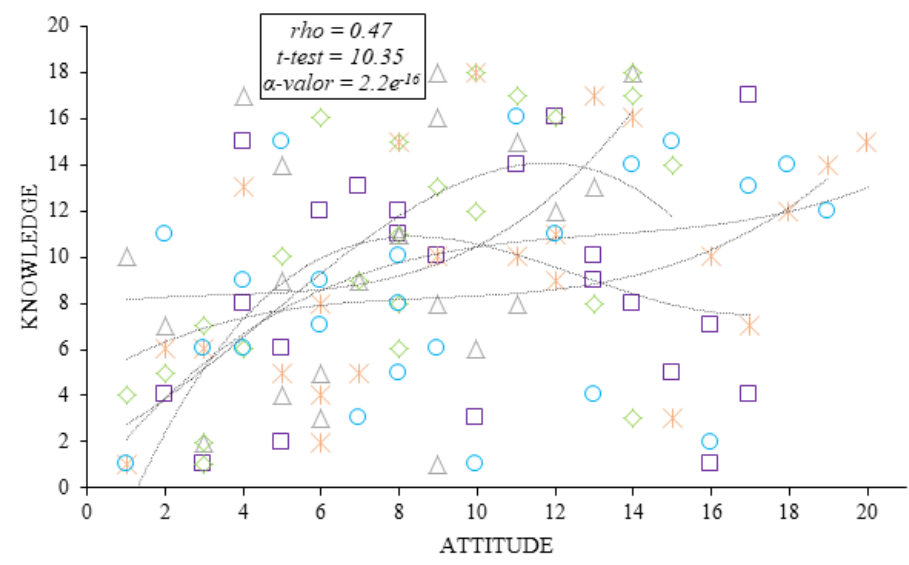

$\square$ Strongly Agree $\triangle$ Agree $\gg$ In Disagreement $\Varangle$ Neither Agree nor Disagree $\bigcirc$ Strongly Disagree

Figure 6: Relationship between Attitude and Environmental Knowledge towards Eco-efficiency in the inhabitants of the Chilca district. The displacement of the data is ordered, transformed and replaced by their respective total order (382) for the rho Spearman relation at the personal level, at 5 levels. 
The attitude and knowledge of the inhabitants present a good relationship, the 382 people surveyed, presenting a general idea of the environmental problems that occur, thus leading to conserve, save and avoid environmental deterioration from an Eco-efficient and eco-environmental perspective. That is why it is intended to seek a general idea of the knowledge and attitude towards eco-efficiency by undoing both concepts. Figure 7 shows that each idea interferes at a personal level; if this change occurs at a personal level, it will influence the urban level forming a polymath and eco-efficient environmental psychology for a sustainable urban environmental development.

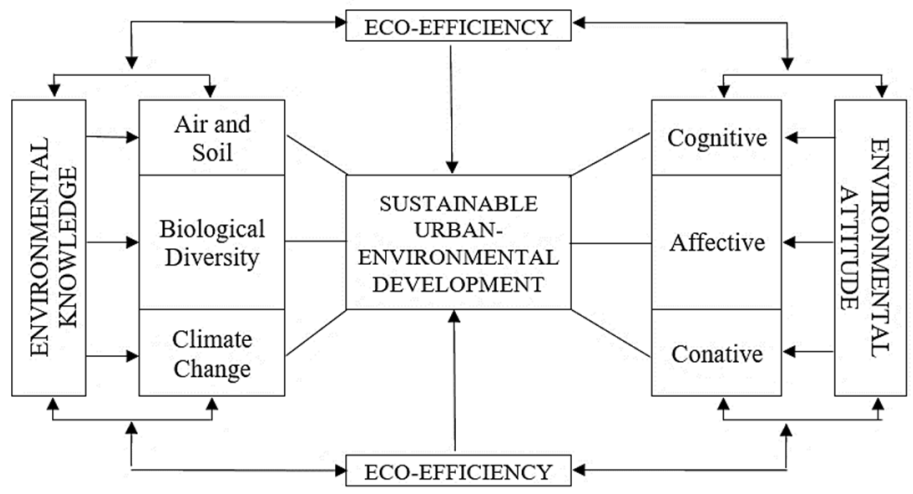

Figure 7: Diagram of Sustainable Urban-Environmental Development, from a personal perspective. The Environmental Knowledge and Attitude is perfected by its respective dimensions which would help to better understand the environmental problems of knowledge and would provide an idea of behavior on a personal level, thus originating to take natural resources from an Eco-efficient measure for a Sustainable Urban Development, Source: Own elaboration.

The personal opinion of the inhabitants of the Chilca district and its main avenues affirms that if they totally agree to agree that the social perception of environmental knowledge and attitude is as important for eco-efficiency and sustainable urban development, as can be Observe in Figure 7, first there is a general idea of the cognitive and conative affective aspect towards eco-efficiency and then towards sustainable urban development and this happens in the same circumstance with the knowledge of soil, water, biological diversity and climate change, where exactly the eco-efficiency supports the sustainability of sustainable urban development; where there may also be a direct participation of the six indicators so that eco-efficiency is not indirectly involved.

\section{Discussions}

\subsection{Environmental Knowledge and Attitude at a Personal Level towards Eco-efficiency}

There is research where they analyzed the attitude and knowledge of people towards the environment considering "eco-efficiency" as a primary issue. Eco-efficiency has promoted on a personal level by having a behavior to reduce the consumption of natural resources; which is evidenced in the following investigations compared with the scientific contribution made in the district of Chilca.

At the national level, the research carried out by Diaz Escobar, (2019) in Manzanari - Satipo affirms that a good environmental management helps to have an eco-efficient knowledge at a personal level. So having environmental knowledge helps to be eco-efficient. This is how this happens continuously with research carried out at an international level. In Latin America Colombia 
implemented the eco-efficiency for an environmental responsibility who conceptualizes Montes Vásquez, (2008) where he mentions that having a good environmental attitude helps to be better eco-efficient at personal level which affirms us with the research done. An environmental attitude is essential to make responsible use of natural resources, furthermore, other investigations in international countries are very interested and the issue of eco-efficiency for sustainable development or/and sustainable environmental-urban development takes it very importantly. Czibere et al., (2020) conducted studies in Switzerland, Italy, Holland, Germany and Hungary where it mentions that people fully agree to be eco-efficient to reduce energy consumption and an environmental behavior or/and attitude would help to minimize consumption irrational nature of natural resources. Agree to our research having an environmental idea or attitude towards eco-efficiency helps at a personal level to reduce the irrational consumption of available natural resources.

Bleischwitz, (2003) joins the research on attitudes where they affirm that a cognitive perspective helps companies or institutions to be eco-efficient in economic environmental management issues and future benefits. According to our research, we did not carry out the economic part, so an economic environmental attitude would also help us to be better in eco-efficiency. Bohne et al., (2008) adds to the research carried out in Norwegian cities where they use two of the $3 \mathrm{R}$ terms to recycle and reuse to have an eco-efficient dynamic for construction institutions applied to their employees and construction managers. We affirm that a behavior towards the use of the ${ }_{3}$ Rs helps people and companies to have an eco-efficient dynamic, this teaches us that if a person on an avenue or urban area has the knowledge to recycle and reuse the other people around them, they will also continue their steps and better implement the use of new post-recycled materials.

We have already observed that other countries have an environmental awareness and attitude to be better on the issue of eco-efficiency on a personal level, but there are three countries that take the issue of eco-efficiency very seriously. Starting in London - England research carried out by Frischknecht, (2010) who applied a questionnaire on recycling life cycle to a group of people asking if the implementation of ISO 14044 is adequate. We have already observed that other countries have an environmental knowledge and attitude to be better eco-efficient at a personal level, but, there are three countries that take the issue of eco-efficiency very seriously and it starts with London - England by. Who applies the recycling life cycle to a set of people where he asks them about the implementation of ISO 14044? Unfortunately, in our research we did not ask the inhabitants about the implementation of ISO 14044, so it would be helpful to mention if the municipality of Chilca is informed about this standard for eco-efficient environmental management.

The following research carried out in Japan by Zheng, (2010) applying a survey, determined the important resources for the population: buying ecological goods, recycling, saving water, saving energy, traveling by public transport and buying organic vegetables, were the resources most captured by the inhabitants, then we also do not ask: are the various types of resources mentioned in our survey important to the inhabitants of Chilca? definitely yes and no. "The yes" is for the issues of recycling, saving water and energy and "The no" for not asking about ecological goods. Then we can appreciate that there may be different resources that will bring awareness and attitude to grasp environmental issues and a general idea that means "Eco-efficiency". We end up with one of the countries that takes Eco-efficiency "China" too seriously, research carried out by Zhang \& Yang, (2007) where they analyzed eco-efficient Urbanism, Eco-environment, Metabolisms, Eco-efficient Dynamics and the implementation of the ${ }_{5} \mathrm{R}$, from 1998 to 2004. His research showed that Chinese cities have more appreciation towards Eco-efficiency where he affirms that having a good attitude and responsible commitment to the environment, the economic state, water service, electricity and other resources will increase the perception, knowledge and environmental attitude of different ages. Yin et al., (2014) also carried out similar research by means of a survey where they affirm the implementation of the ${ }_{5}$ Rs can serve to be a more eco-efficient city, compared to the research carried out in Chilca we do not consider the use of ${ }_{3}$ Rs and much less at ${ }_{5}$ Rs. An opinion similar to the previous text is mentioned Basuki, (2015) where he leads his implementation of the 5 Rs for sustainable development, which is believed to be a very important contribution to eco-efficiency. 
Comment that was also not questioned in the research carried out in the inhabitants of Chilca but we believe that a person with greater environmental knowledge and attitude can be updated on issues of ${ }_{5}$ Rs, ${ }_{3}$ Rs and Sustainable Development to be a more eco-efficient city.

To understand the social perception presented by the inhabitants of Chilca on issues of knowledge and environmental attitude towards eco-efficiency, authors such Bai et al., (2018); Caiado et al., (2017); Fang \& Wang, (2013); Huang et al., (2018) taught us that there are different opinions about these issues and that it has been taking place from 2003 to 2015 in different cities of China. Where all their research takes them beyond responsibility, attitude and environmental knowledge to have an eco-efficient city. And we raise awareness of the rapidly growing urban growth issue, an extremely important issue to control affective, cognitive and conative behavior. Therefore, our research mentioned by different authors led us to a conclusion. A lot of information is needed on environmental, eco-environmental, $3-5$ Rs, recycling dynamics, eco-urban, pro-environmental, etc., to have a good knowledge and personal attitude towards eco-efficiency.

\subsection{Environmental Knowledge towards Eco-efficiency}

It has been observed at a personal level the influence of attitude and knowledge towards ecoefficiency, now we observe with numerical data the environmental knowledge towards eco-efficiency carried out by different investigations. At a national level there is research that helps to observe such variations of knowledge, in Juliaca Condori Cama, (2016) applied a questionnaire to students from different schools where they affirm 188 students have environmental knowledge to reduce consumption to be better in eco-efficiency, 402 a regular knowledge and 306 deficient. Then we can affirm the following that a different age can have a different knowledge, since, our survey was applied to people with the age between 30 - 50 years and students does not reach the age of 20 then this could have influenced in the question. On the other hand, students are more informed in environmental education issues and also in other topics referred, then it is not possible to have a misinformation to make environmental knowledge towards eco-efficiency, since it was observed in general that the inhabitants of Chilca $84 \pm 225$ [ranging from air and soil, biodiversity and climate change] have an idea totally in agreement and in agreement of environmental knowledge towards eco-efficiency.

For its part in the Cercado of Lima Cabana, (2017) applied a questionnaire to determine the level of knowledge of its workers despite a total of 30 employees obtained 13 people who have an optimal knowledge towards eco-efficiency, 15 regular and 2 not at all optimal. Then we can mention that the older the age, one person or several have a knowledge about eco-efficiency. Similarly in Lima but now in Ate Ruelas Llerena, (2017) analyzed the level of eco-efficiency in the employees of the Municipality of the place with a total of 175 people, 80 has an acceptable knowledge, 63 moderately acceptable and 32 not at all acceptable then we can say that definitely a set of people who present greater communication about the environmental issue towards eco-efficiency and that at a respectable age will have greater interest in that topic. Also in Ambo - Huanuco Leon, (2019) found that 23.3\% of its employees of the municipality only possess such environmental knowledge towards eco-efficiency in water and solid waste issues. According to our opinion, this information is sad because if this data is real and if it occurs outside the capital, it is not good for economic development. Although their data is low, the research carried out in Chilca is not in percentage data and if we take it to percentage we can also conclude with the same opinion as Leon, (2019).

At the "José Faustino Sánchez Carrión Arévalo University", research carried out by Arévalo \& Cueva, (2019) showed that a total of $38 \%$ of the students have an environmental knowledge towards environmental problems, where they have greater interest in issues of water consumption, electricity, solid waste, fuel, consumption of paper and materials. The opinion of university students to environmental problems is located more in the university and not outside the institution, in addition they use these types of materials for their education that is why their numerical responses are low to the data compared in the city of Chilca. An international data in Venezuela by Fernández et al., (2010) 
determined the eco-efficiency of SMEs based on their knowledge, thus stating that $67 \%$ of companies have a knowledge in reducing products and processes to recover the defective problems of their Business. So this data can be very important since according to the information of the companies they rose economically through concern, knowledge and environmental awareness, and this data can provide a scientific contribution to institutions, corporations and urban areas within the district of Chilca. The results showed that we did not exceed $50 \%$ in presenting a good eco-efficiency. Therefore, we can affirm that age, communication cooperatives can be very influential to have an environmental knowledge so that the natural resources used are not lost and that eco-efficiency thrives on a personal and institutional level.

\subsection{Environmental Attitude towards Eco-efficiency}

If knowledge is a fundamental part of eco-efficiency, much more is the environmental attitude. Differences attitudes have been observed from the educational institutional level to an urban level. In Huancayo in the secondary educational institution "María Inmaculada" Arteaga Arteaga et al., (2019) individualized the attitude to demonstrate in the best way the attitude of students towards ecoefficiency. According to their research, 39.7\% of students have an affective attitude towards ecoefficiency. Although our surveyed data does not present a percentage form, we can affirm that the attitude of the people of Chilca is more aware of environmental problems than the students of said educational institution. This happens continuously with the cognitive state with $38.8 \%$ and $45.3 \%$ conative, as mentioned above, despite the fact that educational institutions have an environmental program in their teachings, the statistical data that is compared with the surveys in the inhabitants of Chilca $92 \pm 141$ [in their affective, cognitive and conative states] being mostly very high.

So if we can confirm that people's attitudes towards eco-efficiency are totally in accordance with their attitude. In the capital it can be observed that there are also different attitudes towards ecoefficiency, for example, in Acora - Lima, research carried out by Parillo et al., (2019) in an educational institution, students are more affective in the face of environmental problems and eco-efficiency, where their statistical data of the conative and cognitive state exceed $81.1 \%$ mentioning that the students have a concept towards eco-efficiency. It can be inferred that the educational institution teaches environmental programs well and this influences students to be more eco-efficient, according to our research the questionnaire was not applied to students, but we can assume that the students' teachings can contribute to knowledge and attitude of the people of Chilca and in different urban areas.

In the institution "Jesús María" Portal, (2018) I analyze the "Eco-franciscan" program for students from an attitudinal perspective, verifying that $87.5 \%$ of students present an environmental attitude towards eco-efficiency at a general level, as well as their affective state $84 \%$, cognitive $87.5 \%$ and conative $71.9 \%$. These data are very impressive since it is close to the level of understanding of the environment made to the citizens of Chilca, then we can affirm that some educational institutions provide support at an attitudinal level to the student by conserving the environment from the eco-efficient aspect and that it can serve support for the elderly.

In the city of Juliaca - Puno Condori, (2016) conducted a survey at the "Universidad Andina Néstor Cáceres Velásquez" to determine the environmental attitude of 896 students, verifying that 354 students have a favorable cognitive attitude towards the environment, with a very low result. Previously, the range of attitude carried out in our research is almost similar since it also does not exceed $+50 \%$ of people with a good attitude since it is found in $92 \pm 141$ of the 382 . Which is the opposite with the affective aspect with a total number of 587 university students, although this is not repeated with the conative aspect with 174 students. Therefore, we can deduce that the affective attitude is more effective towards eco-efficiency and this attitude can improve and increase the behavior of the inhabitants of Chilca. The most important term of the attitude is "directing the feelings of concern with seriousness or problem that happens towards the environment" we are not sure if this attitude has an influence on the inhabitants of Chilca since its greatest data is in "137" > 141" 
[conative]. It is important to inquire about the questions and knowledge of the students that led to the affective state being more appreciated and how it would help the inhabitants of the Chilca district to have a more eco-efficient attitude.

In the district of Cercado de Lima - Peru Cabana Urquia, (2017) analyzed and evaluated at a personal level employees of an institution called "Management of the City and the Environment" where their environmental attitude towards eco-efficiency is 8 people out of a total of 30 . Despite being a small institution, this could not have happened since there is greater communication and being an institution in the environmental area. This means that, "if an institution that is owned by the government and preferably the environmental sector" its attitude towards eco-efficiency is totally lousy, it is not preferable to trust its environmental sanctions. We can also deduce that the environmental management system in Peru is not being applied correctly, that is why if this problem is evident in the capital Lima, this can influence the inhabitants of Chilca and throughout Peru. We can also mention that there is this type of problem in the Municipality of the Conchamarca de Ambo district - Huánuco, research carried out by Leon, (2019) where I register an attitude that is less than $30 \%$, its most important consumption being the electrical system. An international comparison in the cities of Beijing, Seoul, Taipei and Tokyo in Japan carried out by Zheng, (2010) also recorded their environmental attitudes a little $+30 \%$ "but it is still an eco-efficient city or country" teaching us that the attitude environmental or pro-environmental behavior is related to demographic, socioeconomic, socio-environmental problems, etc. We can analyze with the various investigations what really happens with the Chica district so that it has more experience in eco-efficiency from the attitudinal point of view. We can mention that the affective state, a good teaching or personal attitude and good management by the supervisory authorities help to have a good environmental attitude towards the conservation of natural resources to have a more eco-efficient city for urban development.

\subsection{Environmental Knowledge and Attitude towards Eco-efficiency}

Culminating with the research, the knowledge and attitude towards eco-efficiency are analyzed with a correlational approach, determining the importance towards the environment for urban development. The main topic of this research is Eco-efficiency in Juliaca, research mentioned by Condori, (2016) the relationship between both concepts is rho $=0.33$ compared to our research carried out in Chilca, the result is lower. This could happen since it was mentioned above, educational institutions do not raise the issue of Eco-efficiency well and this influences learning at the urban level and precisely at the personal level. In the following research, this result was also shown in the students of María Inmaculada in Huancayo, a research carried out by Arteaga et al., (2019) where the relationship between attitude and conservation in terms of Eco-efficiency obtained a result of $36.9 \%$. Criticizing this result since it is not possible for students to present this type of knowledge in the face of this problem. Since if these educational teachings are shared at the family level, the results towards eco-efficiency will be disastrous for a growing city.

In the Municipality of Ate by Ruelas, (2017) it obtained a very high relationship due to its low attitude on the part of its employees, they are more eco-efficient with $90.6 \%$ and that this is super high compared to the results found in the district of Chilca. The third concept of approach was from Booi \& Teck, (2010) where their relationship integrated the concepts of attitude, environment, environmental problems, eco-efficiency and ecological products at the University Malaysia to 200 students, thus confirming the relationship of rho $=0.86$. This result is super higher than the relationship found in our research rho $>0.47$ since 382 people were surveyed, both validated through the statistical test, but we both affirmed that there is a significant relationship between both. A primary difference of both investigations [University of Malaysia vs Urban Zone of Chilca] is that the survey was applied to people with a higher education while our investigation was applied to people whose profession is not determined and that each one has their point of view or opinion on the matter and their respective experiences in the field.

In the Management of "Services to the City and Environment" carried out by Cabana Cabana, 
(2017) the relationship between Environmental Attitude and Eco-efficiency in employees obtained $45.7 \%$ as mentioned above, it is not possible that being an environmental institution obtain lower results these environmental problems and that this result is almost a little higher than the rho $=0.47$ found in the urban area of Chilca. In the city of Huánuco, a research carried out by Leon, (2019) in the Municipality of Conchamarca, a result was slightly higher than the previous one, the result of the relationship between environmental management and eco-efficiency is rho $=0.61$. This indicates that people have greater importance on the use of water consumption, electricity, solid waste management and the use of paper or other materials, providing a singularity of the importance of eco-efficiency and natural resources that is used at the institutional level and population.

At the international level, as explained, China is one of the countries that gives importance to this issue of eco-efficiency Bai et al., (2018) explored the eco-efficient relationship of some highgrowth cities from 2006 to 2013 , its relation $p=2.2 \mathrm{e}^{-16}$ who affirms that a rapidly growing city will contain an Eco-efficiency policy for economic and environmental development. This concept is very important and essential for the city of Chilca since it is in an urbanized growth and economically developing. Liu et al., (2012) also showed us that in 30 cities in China they have greater knowledge and attitude towards eco-efficiency with its significant relationship of rho $=0.88>$ [0.47 Chilca] implementing pro-environmental eco-urban cities and environmental development. We highlight these concepts so that a future investigation will remind us of the impacts of these environmental activities and the term eco-efficiency for the inhabitants of Chilca or other government institutions.

We finalize our research with two foreign institutions that helps us understand the importance of eco-efficiency in terms of knowledge and attitude given in Sonja et al., (2018). It showed that students from Germany and Argentina have significant relationships with their respective confirmation tests $\left[60 \%\right.$ and $75 \%, t_{1}=1.96$ and $t_{2}=1.96$ respectively Germany and Argentina; rho $=$ 0.47 and $t=10.35$ ] being helpful to mention that both educational institutions and people from different cities can understand that eco-efficiency is totally safe for urban economic and environmental growth from a personal and urban perspective. Therefore, we can conclude that many national international institutions present a concern, attitude, and environmental knowledge towards eco-efficiency if this is occurring in their behavior, perception and political action. Also if an urban space presents economic and technological demographic growth without altering the environment and being eco-efficient people, this attitude arises as knowledge can influence different urban points.

\section{Conclusions}

All the avenues of the Chilca district present and have a good social perception [totally agree to conserve, recycle and use natural resources efficiently]. And they consider that environmental awareness and attitude is considered of utmost importance for eco-efficiency as a good indicator of sustainable urban development.

The inhabitants of the district of Chilca have a knowledge of conservation of air and soil, biological diversity [267, 290 and 225 respectively] and do not totally disagree [4, 2 and 5 respectively] and an attitude of total agreement in their cognitive, affective and conative environmental ideas [200, 192 and 191 respectively] and do not totally disagree [5, 4 and 4 respectively] towards eco-efficiency.

The relationship between knowledge and environmental attitude towards eco-efficiency is rho $=0.47, \mathrm{t}=10.35$ and $\mathrm{p}=2.2 \mathrm{e}^{-16}$ affirming that there is a commitment by the inhabitants of the district of Chilca to be responsible use of natural resources for an eco-efficient urban development.

Standards such as ISO 14044 , the use of the ${ }_{5} \mathrm{R}$ and environmental programs in government institutions, municipalities, educational centers and urban populations on environmental issues must be implemented to raise environmental awareness and attitude towards "Eco-efficiency".

At a personal or/and urbanism level a commitment is required from the citizens become acquainted in the topics of environmental management, environmental policies, eco-environmental, eco-urban, pro-environmental to better understand the environmental attitude and knowledge; and, to convert urban places in an eco-efficient environmental polymath and psychology in the 
consumption of natural resources to a sustainable environmental-urban development and to create a responsible commitment for regenerative development.

\section{References}

Álvarez, P., \& Vega, P. (2009). Environmental Attitudes and Sustainable Behaviors. Implications for Environmental Education. Revista de Psicodidáctica, Volumen 14(2), 245-260. https://ruc.udc.es/dspace/bitstream/handle/2183/19179/Vega_Marcote_2009_Actitudes_ambientales_ conductas_sostenibles.pdf

Arévalo, Y., \& Cueva, O. (2019). Eco-efficiency plan to improve environmental management at the José Faustino Sánchez Carrión National University [Universidad Nacional José Faustino Sánchez Carrión]. In Universidad Nacional José Faustino Sánchez Carrión (Vol. 6, Issue 1). http://repositorio.unjfsc.edu.pe/bitstream/ha ndle/UNJFSC/2626/ARÉVALO VILLAFUERTE y CUEVA GUEVARA.pdf?sequence $=1 \&$ isAllowed $=y$

Arteaga Aguilar, J., Zárate Quiñones, R., \& Zuñiga Lapa, H. (2019). Attitudes towards Environmental Conservation in students of a secondary educational institution. Horizonte de La Ciencia, 9(16), 9. https://doi.org/10.26490/uncp.horizonteciencia.2019.16.474

Austermühle, S. (2012). Sustainability and eco-efficiency in the modern company. In UPC (Ed.), Sostenibilidad $y$ ecoeficiencia en la empresa moderna (Vol. 1, Issue 1). Universidad Peruana de Ciencias Aplicadas S. A. C. https://repositorioacademico.upc.edu.pe/bitstream/handle/10757/347185/UPC libro sostenib. y ecoef. interiores.pdf?sequence $=1$ \&isAllowed $=y$

Bai, Y., Deng, X., Jiang, S., Zhang, Q., \& Wang, Z. (2018). Exploring the relationship between urbanization and urban eco-efficiency: Evidence from prefecture-level cities in China. Journal of Cleaner Production, 195(1), 110. https://doi.org/10.1016/j.jclepro.2017.11.115

Barreiro, J., López, M., Losada, F., \& Ruzo, E. (2002). Analysis of the cognitive and affective dimensions of the ecological behavior of the consumer. Revista Galega de Economía, 11(2), 22. https://www.redalyc.org/pdf/3 91/Resumenes/Resumen_39111205_1.pdf

Basuki, B. (2015). Eco-Efficiency and Sustainable Development as Efforts to Produce Environmentally Friendly Product: An Exploratory Case Study. Issues In Social And Environmental Accounting, 9(3), 199-217. https://doi.org/10.22164/isea.v9i3.105

Berenguer, J. (1998). Environmental attitudes and beliefs a psychosocial explanation of ecological behavior [Universidad Autónoma de Madrid Facultad de Psicología]. In Universidad Autónoma de Madrid Facultad de Psicología. http://hdl.handle.net/10486/4436

Bleischwitz, R. (2003). Cognitive and institutional perspectives of eco-efficiency. Ecological Economics, 46(3), 453467. https://doi.org/10.1016/So921-80o9(03)oo186-1

Bohne, R. A., Brattebø, H., \& Bergsdal, H. (2008). Dynamic eco-efficiency projections for construction and demolition waste recycling strategies at the city level. Journal of Industrial Ecology, 12(1), 52-68. https://doi.org/10.1111/j.1530-9290.2008.00o13.x

Booi Chen, T., \& Teck Chai, L. (2010). Attitude towards the Environment and Green Products: Consumers' Perspective. Management Science and Engineering, 4(2), 27-39. https://doi.org/http://dx.doi.org/10.3968/ j.mse.1913035X20100402.002

Cabana Urquia, A. (2017). Environmental awareness, values and eco-efficiency in the Management of Services to the City and the Environment. Lima Fenced. 2016 [Universidad César Vallejo]. In Universidad César Vallejo. http://repositorio.ucv.edu.pe/bitstream/handle/20.500.12692/4373/Cabana_UAF.pdf?sequence=1

Caiado, R. G. G., de Freitas Dias, R., Mattos, L. V., Quelhas, O. L. G., \& Leal Filho, W. (2017). Towards sustainable development through the perspective of eco-efficiency - A systematic literature review. Journal of Cleaner Production, 165, 890-904. https://doi.org/10.1016/j.jclepro.2017.07.166

Chuliá, E. (1995). The environmental awareness of the Spanish in the 199os. ASP Research Paper, 12(a), 1-35. http://www.asp-research.com/sites/default/files/pdf/asp12a.pdf

Condori Cama, M. (2016). Relationship Between Knowledge and Attitude towards Eco-efficiency in Students of Secondary Educational Institutions of the City of Juliaca-2015 [Universidad Andina Néstor Cáceres Velásquez]. In Universidad Andina Néstor Cáceres Velásquez (Vol. 53, Issue 9). http://repositorio.uanc v.edu.pe/bitstream/handle/UANCV/763/TESIS To36_oo44420o_M.pdf?sequence=3\&isAllowed=y

Czibere, I., Kovách, I., \& Megyesi, G. B. (2020). Environmental citizenship and energy efficiency in four european countries (Italy, the Netherlands, Switzerland and Hungary). Sustainability (Switzerland), 12(3), 8. https://doi.org/10.339o/su12031154 
Diaz Escobar, F. (2019). Development of environmental management indicators for the elaboration of the ecoefficiency plan of the district municipality of Mazamari 2018 [Universidad San Ignacio De Loyola]. In Universidad San Ignacio De Loyola. http://repositorio.usil.edu.pe/bitstream/USIL/8988/1/2019_DíazEscobar.pdf

Fang, C., \& Wang, J. (2013). A theoretical analysis of interactive coercing effects between urbanization and ecoenvironment. Chinese Geographical Science, 23(2), 147-162. https://doi.org/10.1007/s11769-013-0602-2

Fernández, M. J. D. L. V., Acevedo, R. R., Reymundo, B. Q., \& Flores, S. C. (2021). Environmental Attitude of the Inhabitants of Nijandaris in the Conservation of Natural Resources - Peru. Journal of Education, Society and Behavioural Science, 34(7), 47-56. https://doi.org/10.9734/jesbs/2021/v34i730345

Fernández Viñé, M. B., Gómez Navarro, T., \& Capuz Rizo, S. F. (2010). Eco-efficiency in the SMEs of Venezuela. Current status and future perspectives. Journal of Cleaner Production, 18(8), 30. https://doi.org/10.1016/j.jclepro.2009.12.005

Frischknecht, R. (2010). LCI modelling approaches applied on recycling of materials in view of environmental sustainability, risk perception and eco-efficiency. International Journal of Life Cycle Assessment, 15(7), 666671. https://doi.org/10.1007/s11367-010-0201-6

Glauser, M., \& Müller, P. (1997). Eco-efficiency: A prerequisite for future success. Chimia, 51(5), $201-206$. http://docserver.ingentaconnect.com/deliver/connect/scs/ooo94293/v51n5/s6.pdf?expires=1592126985\&id=0 ooo\&titleid=10984\&checksum=A18D35B78C192370D9D937Ao2D3558EA

Hoffrén, J. (2001). Measuring the Eco-efficiency of Welfare Generation in a National Economy. The Case of Finland [University of Tamperensis]. In University of Tamperensis (Issue December). https://www.doria.fi/bitstream/handle/10024/176148/xtut_233_dig.pdf?sequence=1\&isAllowed=y

Holahan, C. (2012). Environmental Psychology. In University of Texas at Austin (Editorial). Grupo Noriega. https://es.scribd.com/document/375142998/Charles-J-Holahan-PSICOLOGIA-AMBIENTAL-AF-pdf

Huang, Y., Li, L., \& Yu, Y. (2018). Does urban cluster promote the increase of urban eco-efficiency? Evidence from Chinese cities. Journal of Cleaner Production, 197, 957-971. https://doi.org/10.1016/j.jclepro.2018.06.251

Huppes, G., \& Ishikawa, M. (2008). Eco-efficiency and Its Terminology. Journal of Industrial Ecology, 9(4), 43-46. https://doi.org/10.1162/108819805775247891

Leal, J. (2005). Environment and Development. Eco-efficiency: analysis framework, indicators and experiences. In ONU (Ed.), Revista Desarrollo y Sociedad (CEPAL, Issue 30). https://doi.org/10.13043/dys.30.1

Leon Salazar, L. (2019). Influence of environmental management on the eco-efficiency of the district municipality of Conchamarca, Province of Ambo, Huánuco 2019 [Universidad de Huánuco]. In Universidad de Huánuco. http://repositorio.udh.edu.pe/bitstream/handle/123456789/2170/LEON SALAZAR\%2C Luis Alvaro Enrique.pdf?sequence $=1 \&$ isAllowed $=\mathrm{y}$

Li, D. Z., Hui, E. C. M., Leung, B. Y. P., Li, Q. M., \& Xu, X. (2010). A methodology for eco-efficiency evaluation of residential development at city level. Building and Environment, 45(3), 566-573. https://doi.org/10.1016/j.buildenv.2009.07.012

Liu, Y., Song, Y., \& Arp, H. P. (2012). Examination of the relationship between urban form and urban eco-efficiency in china. Habitat International, 36(1), 171-177. https://doi.org/10.1016/j.habitatint.2011.08.001

Lloclla Gonzales, H., \& Arbulú López, C. (2014). Education in Eco-efficiency. "UCV-HACER" Revista de Investigación y Cultura, 3(Junio), 31-39. https://dialnet.unirioja.es/descarga/articulo/5472521.pdf

Montes Vásquez, J. (2008). Eco-efficiency: a proposal of corporate environmental responsibility to the colombian financial sector [Universidad Nacional de Colombia Sede Medellín]. In Universidad Nacional de Colombia Sede Medellín. https://www.ecobankingproject.org/publicacion/instituciones_academicas/Tesis-JMontes.pdf

Parillo, E., Marca, V., \& Talavera, I. (2019). Attitude of students towards environmental conservation in Acora 2018. Nawparisun - Revista De Investigación Científica, 1(4), 19-24. http://unaj.edu.pe/revista/index.php /vpin/article/view/43/33

Portal, P. (2018). The Ecofranciscan Program in the attitude towards the conservation of the environment in high school students of the private educational institution San Antonio de Padua de Jesús María, 2015 [Universidad Católica Sedes Sapientiae]. In Universidad Católica Sedes Sapientiae. http://repositorio.ucss.edu.pe/bitstream/handle/UCSS/532/Portal_Pedro_tesis_maestria_2018.pdf?sequence $=1 \&$ isAllowed $=\mathrm{y}$

Ruelas Llerena, L. (2017). Environmental management in the eco-efficiency of workers in the municipality of Ate 2017 [Universidad Cesar Vallejo]. In Universidad Cesar Vallejo. http://repositorio.ucv.edu.pe/handle/ UCV/8885

Sonja, M., Dombois, C., \& Funke, J. (2018). The Role of Environmental Knowledge and Attitude: Predictors for Ecological Behavior Across Cultures? Analysis of Argentinean, An Students, German. Umweltpsychologie, 1(January), 69-87. https://www.psychologie.uni-heidelberg.de/ae/allg/mitarb/jf/Geiger etal 2018 ecological behavior across cultures.pdf 
Yin, K., Wang, R., An, Q., Yao, L., \& Liang, J. (2014). Using eco-efficiency as an indicator for sustainable urban development: A case study of Chinese provincial capital cities. Ecological Indicators, 36, 665-671. https://doi.org/10.1016/j.ecolind.2013.09.003

Zhang, Y., \& Yang, Z. (2007). Eco-efficiency of urban material metabolism: a case study in Shenzhen, China. Acta Ecologica Sinica, 27(8), 3124-3131. https://doi.org/10.1016/S1872-2032(07)60067-5

Zheng, Y. (2010). Association Analysis on Pro-Environmental Behaviors and Environmental Consciousness in Main Cities of East Asia. Behaviormetrika, 37(1), 55-69. https://doi.org/10.2333/bhmk.37.55 